\title{
Local Abnormalities of Coagulation and Fibrinolytic Pathways that Promote Alveolar Fibrin Deposition in the Lungs of Baboons with Diffuse Alveolar Damage
}

Steven Idell, Jay Peters, Kathleen K. James, Daryl S. Fair, and Jacqueline J. Coalson

Departments of Medicine and Biochemistry, The University of Texas Health Center at Tyler, Tyler, Texas 75710; and the

Departments of Medicine and Pathology, The University of Texas Health Center at San Antonio, San Antonio, Texas 78284-7550

\begin{abstract}
Because alveolar fibrin is a prominent histologic feature of diffuse lung injury in baboons, we hypothesized that local abnormalities of pathways of fibrin turnover would favor fibrin deposition in the alveolar space. To test this hypothesis, procoagulant and fibrinolytic activities were characterized in serial bronchoalveolar lavage (BAL) of baboons with evolving diffuse alveolar damage (DAD) induced by exposure to $100 \% \mathrm{O}_{2}$. BAL procoagulant activity, characterized mainly as the tissue factor-Factor VII complex, was markedly increased after induction of DAD. Extrinsic pathway inhibitor was likewise increased in BAL during evolving DAD but was insufficient to control coagulation. Urokinase-like fibrinolytic activity was usually detectable in baseline BAL but was undetectable after $7 \mathrm{~d}$ of $\mathrm{O}_{2}$. DAD BAL contained significantly increased plasminogen levels, plasmin inhibitor activity sufficient to neutralize all plasmin produced by BAL plasminogen activator found in control BAL and detectable plasminogen activator inhibitor-1. Antiplasmin activity was due, in part, to increased $\alpha_{2}$ antiplasmin. These changes correlated with quantitatively increased alveolar fibrin deposition demonstrated by histologic and morphometric analyses. Multiple abnormalities of pathways of fibrin turnover occur concurrently in the alveolar compartment of the lungs of baboons with DAD, which collectively predispose to diffuse alveolar fibrin deposition.
\end{abstract}

\section{Introduction}

Alveolar fibrin deposition is a histologic hallmark of acute alveolitis and is particularly prominent in the Adult Respiratory Distress Syndrome (ARDS) ${ }^{1}$ as well as acute lung injuries in experimental animals including diffuse alveolar damage (DAD) in baboons (1-6). We hypothesized that abnormalities of pathways of fibrin turnover occur in alveolar fluids in asso-

Address reprint requests to Dr. Idell, The University of Texas Health Center at Tyler, P. O. Box 2003, Tyler, TX 75710.

Received for publication 13 April 1988 and in revised form 5 January 1989.

1. Abbreviations used in this paper: ARDS, adult respiratory distress syndromes; BAL, bronchoalveolar lavage; $\mathrm{CHF}$, congestive heart failure; DAD, diffuse alveolar damage; EPI, extrinsic pathway inhibitor; FRC, functional residual capacity; NPP, normal pooled plasma; PA, plasminogen activator; PAI; plasminogen activator inhibitor; RLL, right lower lobe; TLC, total lung capacity; t-PA, tissue PA; u-PA, urokinase PA.

J. Clin. Invest.

(c) The American Society for Clinical Investigation, Inc. $0021-9738 / 89 / 07 / 0181 / 13 \$ 2.00$

Volume 84 , July $1989,181-193$ ciation with the high grade alveolitis that characterizes evolving DAD and that these abnormalities favor alveolar fibrin deposition. To test this hypothesis, we analyzed the procoagulant and fibrinolytic activities in serial, unconcentrated bronchoalveolar lavage (BAL) fluids of baboons with evolving DAD induced by protracted exposure to $100 \% \mathrm{O}_{2}$. The histology of this lung injury is characterized by extensive alveolar fibrin, hyaline membranes, varying degrees of alveolitis, and early fibrotic repair. The baboon model of DAD, induced by $100 \% \mathrm{O}_{2}$, was chosen for this study as it bears strong morphologic as well as pathophysiologic resemblance to ARDS, which is likewise characterized by $\operatorname{DAD}(5,6)$.

As a result of microvascular and interstitial injury and/or local elaboration, substrates and inhibitors of coagulation and fibrinolysis may enter the alveoli, a compartment from which they are normally sequestered in the absence of inflammation. Access of such mediators is suggested by the recent demonstration that the composition of alveolar fluids in ARDS is similar to that of plasma (7). We postulated that abnormal entry or local elaboration of these reactants establishes conditions in which local fibrin deposition is favored. Supportive evidence includes recent observations that procoagulant activity is significantly increased in BAL of bleomycin-treated marmosets (3) and patients with ARDS (8), which, in both cases, is temporarily associated with extensive alveolar fibrin deposition.

The role of extravascular fibrin deposition in the pathophysiology of acute lung injury and DAD, in particular, is currently unclear. However, fibrin or fibrin-derived peptides are known to influence endothelial cell function $(9,10)$ vascular permeability (11) and inflammatory cell traffic (12) and thus may influence the inflammatory response (13). Fibrin also serves as a provisional matrix upon which fibroblasts may aggregate and secrete collagen (14), suggesting that fibrin could influence in vivo tissue repair and scarification. Moreover, fibrinolytic and coagulation reactants may activate the complement and kinin-forming systems (15). For these reasons, and because extensive extravascular, primarily alveolar fibrin deposition occurs in the severely injured lung, knowledge of the local abnormalities that promote alveolar fibrin deposition is essential to understanding the pathogenesis of ARDS and related forms of lung injury. In this study, we demonstrate that multiple abnormalities of pathways of fibrin turnover occur in the lower respiratory tract fluids of baboons with evolving DAD and that these abnormalities functionally predispose to the local deposition of alveolar fibrin.

\section{Methods}

Animals. The 17 young adult baboons (Papio cynocephalous) studied were born in captivity, had no history of respiratory disease and were free of parasites. Baseline studies, including chest $x$ rays, pulmonary function tests and arterial blood studies were normal. The protocols used to obtain these physiologic measurements were as previously described (5). Animals were anesthetized with ketamine and main- 
tained under continuous deep sedation with diazepam and muscular paralysis using pancuronium (5). Throughout the course of these experiments, the animals were kept on continuous mechanical ventilation in an intensive care unit-like setting. Details of the protocols for mechanical ventilation and long term management of these baboons have previously been described $(5,6)$. Briefly, animals were ventilated via cuffed endotracheal tubes using a volume cycled ventilator (MA-1; Puritan-Bennett Corp., Kansas City, KS). Additional instrumentation of these animals included placement of a balloon-tipped pulmonary artery catheter, an arterial catheter, and urinary bladder catheter. Trended measurements included electrocardiographic monitoring, determination of systemic and pulmonary vascular pressures, cardiac output determinations and arterial blood gas studies. In addition, daily chest $\mathrm{x}$ rays were followed and serial pulmonary function testing including determination of functional residual capacity (FRC), diffusing capacity (DLCO) and total lung capacity (TLC) were performed.

After collection of baseline data on the first day of each experiment, DAD was induced by exposure to $100 \%$ oxygen ( $n=10$ animals). Alternatively, control baboons were mechanically ventilated while receiving $21 \%$ oxygen ( $n=7$ animals). To prevent bronchopulmonary infection, animals were given ampicillin and polymyxin. Animals received a prophylactic antacid (Maalox; William H. Rorer, Inc., Fort Washington, PA) every $4 \mathrm{~h}$. Fluids were administered intravenously on the basis of blood chemistries, urinary output, and hemodynamic measurements. A fiberoptic bronchoscope (pediatric model; Olympus Corp., Irving, TX) was used to perform BAL, which consisted of the instillation of $90 \mathrm{ml}$ of saline into a single lobe. Baboons exposed to $100 \% \mathrm{O}_{2}$ or controls ventilated with $21 \% \mathrm{O}_{2}$ were instilled with $90 \mathrm{ml}$ of saline. The recovered fluid was centrifuged at $2,500 \mathrm{~g}$ at $4^{\circ} \mathrm{C}$ for 10 $\mathrm{min}$. The pellet was used to determine total and differential white cell counts, while the supernatant was centrifuged at $12,000 \mathrm{~g}$ for $15 \mathrm{~min}$ and the supernatant frozen at $-70^{\circ} \mathrm{C}$ until used. In preliminary experiments, we found that ${ }^{125} \mathrm{I}$ radiolabeled Factor Xa or plasminogen were not altered by the lavage processing procedure. The physical form of these proteins, when added to BAL alone or to BAL supplemented with $1 \times 10^{6}$ human neutrophils $/ \mathrm{ml}$ and then processed as described above, was virtually identical. Plasminogen remained in the $90,000 M_{\mathrm{r}}$ form in saline, as well as baseline or DAD BAL with or without BAL processing. Factor Xa migrated at 53,000 in saline and in baseline BAL but was, in part, complexed at $120,000 M_{\mathrm{r}}$ in DAD BAL, with or without BAL processing. DAD was induced by exposing baboons to $100 \%$ inspired oxygen for 5-9 d. The infusion of dopamine was used to treat severe systemic hypotension which was associated with severe, edematous lung injury necessitating the use of positive end expiratory pressure (PEEP) in three of these animals. BAL was obtained before the initiation of $100 \%$ oxygen and at either 5,7 , and in some cases, $9 \mathrm{~d}$ after exposure.

Seven control animals were mechanically ventilated with $21 \%$ oxygen for 5-11 d. These animals were maintained under the same conditions as those described above. BAL was obtained at day 0,7 , and 11 of control mechanical ventilation as described above.

Histologic and morphometric studies. Autopsy was performed immediately after the death or elective sacrifice of each animal. Lungs were perfused for $15 \mathrm{~min}$ with phosphate-buffered $4 \%$ formaldehyde$1 \%$ glutaraldehyde fixative $(4 \mathrm{CF}-1 \mathrm{G})$ at $28 \mathrm{~cm} \mathrm{H}_{2} \mathrm{O}$ pressure using a rolling pump (16).

Specimens were prepared for light microscopy and transmission electron microscopy as previously described (5). Lung blocks were obtained from the right upper and right middle lobes (one each), studied by routine light microscopy and used for correlation with microbiologic results. The right lower lobe (RLL) was dedicated entirely for pathologic and morphometric studies. After weighing and intrabronchial fixation with phosphate-buffered $4 \%$ paraformaldehyde at $20 \mathrm{~cm}$ $\mathrm{H}_{2} \mathrm{O}$ constant airway pressure for $48 \mathrm{~h}$ (17), the RLL lung volume was determined by volume displacement and transverse $1.0-\mathrm{cm}$ sections were taken at three levels through each lobe (18). The entire surface of each transverse slice of the RLL was totally sampled and blocked for light microscopic studies with an average of 14 blocks being examined.
Determination of both the extent and severity of DAD (either exudative, reparative, or mixed patterns) and pneumonias (graded histologically as organizing, mild, moderate, or severe) was accomplished. Electron microscopy specimens were obtained from 5 or more representative areas of the usual 14 light microscopic sample sites. 50 blocks were fixed in Zetterqvist's osmium fixative of which 20 were then embedded and thick sectioned. Six blocks were then thin sectioned and stained with Reynolds' lead citrate and uranyl acetate. The presence of fibrin within the alveolar space was confirmed by its characteristic periodicity on electron microscopy (19). Volume density determinations of the presence of fibrin within the alveolar space were accomplished on specimens of the $100 \%$ oxygen treated animals and were compared with a group of nonventilated healthy baboon controls using established techniques (20). Three animals were randomly selected from each group for analysis.

Coagulation assays. Single-stage coagulation assays in which BAL was exposed to either normal pooled human plasma or human plasmas deficient in Factors VII, VIII, or X were performed as previously described $(3,8)$. All assays were performed in duplicate using the same lot of each deficient plasma to assay all BAL samples. Extrinsic pathway inhibitor (EPI) activity was measured in a three-stage coagulation assay, as previously described (21). A standard curve was constructed from pooled normal human plasma and showed a direct linear relationship between the logarithm of the clotting time and the logarithm of the plasma containing EPI between $0.2-8 \%$, assuming $100 \mathrm{ng} \mathrm{EPI} / \mathrm{ml}$ plasma (21).

Amidolytic assay of Factor Xa. Conversion of Factor X to Xa by baboon BAL was determined by an amidolytic assay performed as previously described, with slight modifications (8). In this assay, $45 \mu 1$ of BAL was incubated with $30 \mu 1$ of $0.15 \mathrm{M} \mathrm{NaCl}, 0.02 \mathrm{M}$ Tris, $\mathrm{pH} 7.4$ (TBS), and $15 \mu \mathrm{l}$ human Factor $\mathrm{X}(10 \mathrm{U} / \mathrm{ml})$. This mixture was incubated at $37^{\circ} \mathrm{C}$ for up to $30 \mathrm{~min}$. $75-\mu \mathrm{l}$ aliquots were added to a spectrophotometer cuvette containing $25 \mu \mathrm{l}$ of $4 \mathrm{mM}$ benzoylisoleucyl-glutamyl-glycyl-arginine-p-nitroanilide (S2222; Kabi Group, Inc., Greenwich, CT) and $200 \mu \mathrm{l}$ of $50 \mathrm{mM}$ Tris, $175 \mathrm{mM} \mathrm{NaCl}$, and $7.5 \mathrm{mM}$ EDTA, $\mathrm{pH}$ 8.4. The initial rate of increase in absorbance at $405 \mathrm{~nm}$ was determined on a response spectrophotometer (Gilford Instruments, Inc., Oberlin, $\mathrm{OH}$ ). The picomoles of Factor X hydrolyzed per minute per milliliter of BAL was calculated based on the initial rate of increase of absorbance generated by human Factor Xa standards as previously described (3).

Proteolytic cleavage ${ }^{125}$ I-labeled human Factor X. Factor X was labeled with $\mathrm{Na}{ }^{125} \mathrm{I}$ as previously described (8). Baboon BAL was incubated at $37^{\circ} \mathrm{C}$ with a mixture of radiolabeled and unlabeled human Factor $X(5 \mu \mathrm{g} / \mathrm{ml})$ in polypropylene tubes for $30 \mathrm{~min}$. Aliquots were removed and subjected to nonreduced SDS polyacrylamide gel electrophoresis (SDS-PAGE) and autoradiographic development of the dried gel as we have previously described $(3,8)$.

Neutralization of $B A L$ Factor $X$ activating activity by antibodies to Factor VII and tissue factor. Equal volumes of baboon BAL and rabbit antibodies (IgG fraction) to Factor VII $(50 \mu \mathrm{g} / \mathrm{ml})$, tissue factor $(100$ $\mu \mathrm{g} / \mathrm{ml}$ ), or nonimmune $\mathrm{IgG}$ were incubated for $1 \mathrm{~h}$ at $37^{\circ} \mathrm{C}$ after which BAL Factor $\mathrm{X}$ activating activity was determined in the Factor $\mathrm{Xa}$ amidolytic assay. Characterization of the neutralizing antibody to human Factor VII has been previously described (22). Antibody to bovine tissue factor, which cross-reacts with human tissue factor (23, 24), was generously provided by Dr. Ronald Bach (Yale University, New Haven, CT).

Fibrin plate assay of BAL fibrinolytic activity. Plasminogen activator (PA) activity and plasminogen independent fibrinolytic activity of baboon BAL was assayed in ${ }^{125} \mathrm{I}$-fibrin plates as previously described $(25,26)$. The sensitivity of the assay performed as described was 0.0001 $\mathrm{IU} / \mathrm{ml}$ based on urokinase standards (American Diagnostics, Inc., Greenwich, CT). PA activity of BAL was determined by calculation of the time at which $50 \%$ of trypsin releasable radioactivity was achieved by the sample.

Neutralization of fibrinolytic activity in baboon BAL. Baboon BAL was preincubated with a final concentration of $160 \mu \mathrm{g} / \mathrm{ml}$ of the $\operatorname{IgG}$ 
fraction of antibodies to urokinase (u-PA), tissue plasminogen activator (t-PA), control goat IgG or normal saline solution for $30 \mathrm{~min}$ at $37^{\circ} \mathrm{C}$, and analyzed in the ${ }^{125} \mathrm{I}$-fibrin plate assay. The goat antibodies were purchased from American Diagnostica (Greenwich, CT), and their specificities confirmed. The t-PA was generously provided by $\mathrm{Dr}$. Eugene Levin (Research Institute of Scripps Clinic, La Jolla, CA).

Characterization of $P A$ and $P A$ inhibitory activity in baboon $B A L$. PA of baboon BAL was also characterized by fibrin gel autography, as described by Levin and colleagues (27). Briefly, BAL samples or standards were subjected to SDS-PAGE using $10 \%$ acrylamide resolving gels (3). The gel was then soaked in $0.1 \mathrm{M}$ sodium phosphate $\mathrm{pH} 7.2$ with $2.5 \%$ Triton X-100, blotted dry and placed on top of a freshly prepared fibrin indicator gel. The indicator gel was allowed to develop at room temperature in a moist chamber, and the resulting clear lysis zones were photographed. Reverse fibrin gel autography was performed as previously described (28). Samples were subjected to SDSPAGE, the gel soaked in Triton X-100 and then placed over a fibrinagar indicator plate supplemented with $0.075 \mathrm{IU} / \mathrm{ml}$ of urokinase (final concentration). Regions of the gel containing inhibitor were revealed by the formation of opaque, lysis-resistant zones in the clear, lysed indicator gel.

Antiplasmin activity. Antiplasmin activity of BAL samples was measured by incubating with equal volumes of $5 \mu \mathrm{g} / \mathrm{ml}$ plasmin (American Diagnostics) diluted in normal saline and BAL samples at $37^{\circ} \mathrm{C}$ for $30 \mathrm{~min}$. Aliquots were analyzed in the ${ }^{125} \mathrm{I}$ fibrin plate assay to determine the residual fibrinolytic activity of the sample-plasmin mixtures.

Alternatively, antiplasmin activity was measured by a decrease in the initial rate of plasmin-mediated hydrolysis of the chromogenic substrate H-D-Val-Leu-Lys-p-nitroanilide (S-2251; KABI Group, Inc.) (29). Briefly, $50 \mu \mathrm{l}$ of plasmin ( $10 \mu \mathrm{g} / \mathrm{ml}$ in TBS) was mixed with $50 \mu \mathrm{l}$ of normal saline or BAL samples, incubated at $37^{\circ} \mathrm{C}$ for $10 \mathrm{~min}$ and then added to prewarmed spectrophotometer cuvettes containing $25 \mu \mathrm{l}$ of $3.5 \mathrm{mM} \mathrm{S}-2251$ and $175 \mu \mathrm{l}$ of TBS. Initial rates of cleavage of the substrate were assessed by the change in absorbance at $405 \mathrm{~nm}$ using a spectrophotometer (DU 30; Beckman Instruments, Inc., Fullerton, CA) and were linear for at least $5 \mathrm{~min}$. The rates were converted to micrograms per milliliter of plasmin based upon the amidolytic activity generated by plasmin standards. Residual plasmin activity of the plasmin-BAL samples was expressed as percent inhibition relative to the plasmin standard mixed with saline. Expression of amidolytic activity by plasmin was unaffected by addition of up to $2 \mathrm{mg} / \mathrm{ml}$ asolectin (American Lecithin Co., Woodside, NY), which represented 100 times the phospholipid content we previously reported in BAL of patients with ARDS (8). Addition of up to $10 \mathrm{mg} / \mathrm{ml}$ of bovine serum albumin likewise did not interfere with plasmin-mediated amidolytic activity.

Goat antibody to human $\alpha_{2}$-antiplasmin $\left(\alpha_{2} \mathrm{AP}\right)$ and control goat IgG were purchased from American Diagnostics and bound to Affigel10 beads (Bio-Rad Laboratories, Richmond, CA), according to the manufacturer's instructions at a ratio of $5 \mathrm{mg} \mathrm{IgG/ml} \mathrm{of} \mathrm{resin.} \alpha_{2} \mathrm{AP}$ (American Diagnostics) was shown to inhibit plasmin, when it was diluted to $10 \mu \mathrm{g} / \mathrm{ml}$ in TBS and then mixed for $10 \mathrm{~min}$ at $37^{\circ} \mathrm{C}$ with 10 $\mu \mathrm{g} / \mathrm{ml}$ plasmin. This inhibitory capacity was removed if $\alpha_{2} \mathrm{AP}$ was incubated for $1 \mathrm{~h}$ at $37^{\circ} \mathrm{C}$ with antibody to $\alpha_{2} \mathrm{AP}$ bound to Affigel-10 but was unchanged after adsorption with control beads. BAL samples were incubated with either anti- $\alpha_{2} \mathrm{AP}$ or control beads $1: 1$ (vol/vol) for $1 \mathrm{~h}$ at room temperature, and the beads were then sedimented by a flash spin using a Beckman microfuge. Remaining antiplasmin activity was measured in two assays. To $60 \mu \mathrm{l}$ of supernatant was added $60 \mu \mathrm{l}$ of plasmin standard $(6 \mu \mathrm{g} / \mathrm{ml})$ for $10 \mathrm{~min}$ at $37^{\circ} \mathrm{C}$ and the plasmin-mediated amidolytic activity was determined. Alternatively, the supernatants were mixed $1: 1$ with a plasmin standard $(1.25 \mu \mathrm{g} / \mathrm{ml}$ in normal saline) for $30 \mathrm{~min}$ at $37^{\circ} \mathrm{C}$ and plasmin-mediated release of radiolabeled fibrin was measured in the ${ }^{125}$ I fibrin plate assay.

Radioimmunoassays. Double antibody competitive equilibrium radioimmunoassays were modified from those previously reported for human plasminogen and $\alpha_{2} \mathrm{AP}$ (29). Proteins were radioiodinated by the dilute chloramine T method (30) to specific activities of 1.7-6.6 $\mu \mathrm{Ci} / \mu \mathrm{g}$. To $250 \mu \mathrm{l}$ of labeled protein $(0.5 \mathrm{nM})$ was added $250 \mu \mathrm{l}$ of competing human protein (for standard curve) or bronchoalveolar fluid (diluted 1:4) and $250 \mu \mathrm{l}$ of antibody diluted to give $\sim 30 \%$ binding of the iodinated ligand. After incubation at $4^{\circ} \mathrm{C}$ for $16-20 \mathrm{~h}, 500 \mu \mathrm{l}$ of goat anti-rabbit (Pel-Freez Corp., Rogers, AR) IgG was added and incubated at $4^{\circ} \mathrm{C}$ for $6 \mathrm{~h}$. The immunoprecipitates were collected by centrifugation at $2,000 \mathrm{~g}$ for $15 \mathrm{~min}$, and $500 \mu$ l of supernatant was counted in a gamma counter. In control studies, semilogarithmic graphs of the inhibition of ${ }^{125}$ I-protein binding to its specific antibody seen by normal baboon plasma was parallel to the competition curves observed for human plasma permitting an estimate of these proteins present in biological fluids. The buffer used for the assay contained 50 $\mathrm{mM}$ Tris/ $\mathrm{HCl}$ (pH 8.0), $25 \mathrm{mM} \mathrm{NaCl}, 10 \mathrm{mM}$ benzamidine, $1 \mathrm{mM}$ PMSF, $5 \mathrm{U} / \mathrm{ml}$ aprotinin, $0.75 \%$ normal rabbit serum, and $0.02 \%$ NaN3. Plasminogen was purified from human plasma by the method of Deutsch and Mertz (31) and human $\alpha_{2} \mathrm{AP}$ was bought from American Diagnostica. Rabbit antibodies to human plasminogen and $\alpha_{2} \mathrm{AP}$ were generously provided by Dr. Edward F. Plow and Dr. Lindsey A. Miles (Research Institute of Scripps Clinic, La Jolla, CA).

Characterization of the form of plasminogen-related antigen in baboon $B A L$. BAL plasminogen related antigen was adsorbed by addition of $20 \mu$ l of lysine-Sepharose 4B (coupled by $\mathrm{CNBr}$; 32) to $1 \mathrm{ml}$ of BAL sample and mixed by rotation at room temperature for $1 \mathrm{~h}$. The beads were collected by centrifugation for $30 \mathrm{~s}$ using a Beckman Microfuge and washed once in normal saline. Plasminogen-related antigen was eluted by boiling the antibody-Sepharose beads for $4 \mathrm{~min}$ in the $2 \%$ SDS, $1 \%$ glycerol, $62.5 \mathrm{mM}$ Tris- $\mathrm{HCl}, \mathrm{pH} 6.8$. Supernatants were applied to $4 \%$ acrylamide stacking gels and run on $10 \%$ acrylamide resolving gels by the method of Laemmli (33). Electrophoretic transfer to nitrocellulose was performed according to Towbin et al. (34) using a Bio-Rad transfer cell with a recirculating water bath $\left(4^{\circ} \mathrm{C}\right)$ at $60 \mathrm{~V}$ for $90 \mathrm{~min}$. The nitrocellulose paper was "blocked" by incubation with 0.5

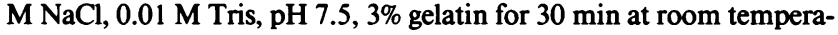
ture, incubated with a 1:200 dilution of rabbit anti-human plasminogen overnight at $4^{\circ} \mathrm{C}$, and reacted with $0.1 \mu \mathrm{g} / \mathrm{ml}^{125} \mathrm{I}$ goat anti-rabbit IgG, radiolabeled according to the method of Fair et al. (30), for 3 min at ambient temperature. Plasminogen derivatives were localized by autoradiography, and the molecular weights of plasminogen species were determined by the relative migration of transferred prestained standards (Bio-Rad Laboratories).

Human pleural fluids. Pleural fluids were collected by standard thoracentesis technique from hospitalized patients in order to examine the specificity of abnormalities of fibrin turnover observed in BAL. Pleural fluids were harvested from patients with congestive heart failure (CHF, $n=6)$, patients with pneumonia and parapneumonic effusions $(n=4)$, empyema $(n=3)$, and patients with carcinoma of the lung and associated pleural effusions $(n=16)$, and were immediately collected in polypropylene tubes containing $3.8 \%$ sodium citrate in a ratio of $9: 1$, pleural fluid/citrate. The fluids were immediately centrifuged at $400 \mathrm{~g}$ for $10 \mathrm{~min}$, after which the pleural fluid total white cell and differential counts and protein content were determined $(3,8)$. The cell-free pleural fluids were then immediately frozen at $-70^{\circ} \mathrm{C}$ until further processing was completed. Pleural fluids were harvested for clinical indications, and the collection of these fluids for this study was approved by the Human Subjects Institutional Committee of The University of Texas Health Center at Tyler.

Statistical analysis. Nonparametric analysis of BAL variables was used as these variables are not known to be normally distributed. Intergroup variation for BAL variables was first determined by Kruskal Wallis 1-way analysis of variance. Specific comparison of BAL variables between groups was done using the Mann Whitney U-Wilcoxon Rank Sum W test. The data are presented as box graphs that show the medians, ranges of $50 \%$ of the data points (boxes) and the entire range of values.

\section{Results}

In the $100 \% \mathrm{O}_{2}$ group, DLCO was usually reduced at day 4 of exposure, suggesting pulmonary oxygen toxicity and chest $x$ 
rays showed diffuse bilateral infiltrates suggesting the development of pulmonary edema by day 5 . Hypotension requiring infusion of dopamine was observed in three animals usually on the fifth to sixth day after oxygen exposure and was believed to be due to the effects of positive pressure mechanical ventilation and worsening lung injury. One animal in the oxygen-treated group succumbed to an episode of hypotension. The others were electively sacrificed at 6 to 9 days after exposure to $100 \% \mathrm{O}_{2}$. BAL obtained at baseline revealed about 1 $\times 10^{6}$ total white cells with greater than $90 \%$ macrophages on differential white cell count. At all time points following injury in oxygen-challenged baboons, BAL contained $10^{6}$ to $10^{7}$ total white cells and a neutrophilic pleocytosis (neutrophils $\geq 30 \%$ ) was observed. About $50 \%$ of the instilled saline was recovered during the lavage procedure. Total protein content in BAL from control and treated baboons was followed for up to $11 \mathrm{~d}$ (Fig. 1). In the oxygen-treated group, an increase in total protein was seen which continued up to day 9 after hyperoxia to $5-6.25 \mathrm{mg} / \mathrm{ml}$. In baboons ventilated with $21 \% \mathrm{O}_{2}$, the $\mathrm{BAL}$ total protein rose from a baseline of $0.02-0.05 \mathrm{mg} / \mathrm{ml}$ to a median of $0.2 \mathrm{mg} / \mathrm{ml}$, which was significant $(P=0.02)$, but was 10 -fold less than that level observed in injured animals with DAD.

Histologic and morphometric observations. Histologic changes in the $100 \%$ oxygen-treated group included exudative DAD characterized by protein-rich pulmonary edema and hyaline membrane formation (Fig. $2 A$ ). Fibrin was abundant in the intraalveolar exudate of these animals (Fig. $2 B$ ). Superimposed upon this process was a pneumonitis characterized by increased numbers of neutrophils (PMNs) in respiratory bronchioles and surrounding alveoli (not shown).

The presence or absence of pneumonia, and DAD was determined histologically in each animal (Table I). Analysis for exudative DAD indicated a diffuse presentation in 7 of 10

\section{BABOON BAL PROTEINS}

100\% OXYGEN

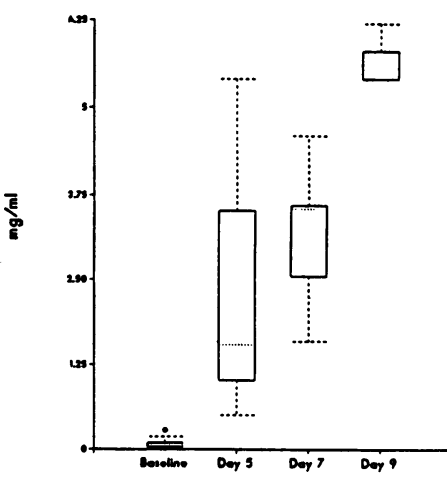

$21 \%$ OXYGEN

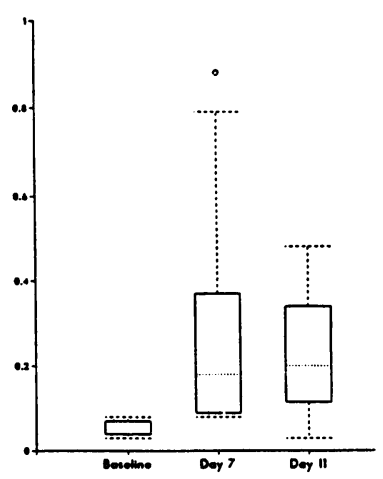

Figure 1. Changes in total protein concentration in serial BAL samples of baboons treated with $100 \%$ oxygen or $21 \%$ oxygen. The data are presented as box plots: open boxes represent the fields which contain $50 \%$ of the values and contain the median value $(\cdots)$. The range of values is indicated by the dashed lines and the circles represent outlying values. Confidence limits are described in the text. baboons treated with $100 \% \mathrm{O}_{2}$ and focal in 2 . None of the control mechanically ventilated baboons developed DAD. Pneumonia was observed in nearly every animal, which varied from mild to moderate in both control $21 \%$ and $100 \% \mathrm{O}_{2}$ treated baboons. Volume density determinations of the presence of fibrin within the alveolar space revealed a significant difference in the animals with DAD compared to a group of nonventilated baboon controls ( $n=3$ in each group). By this morphometric analysis, grossly more fibrin was present in the lungs of animals with DAD as a result of $100 \% \mathrm{O}_{2}$ exposure (Table II). Minimal to no alveolar fibrin was present in the three control animals.

Characterization and quantitation of procoagulant activity present in baboon BAL. Normal baboon BAL was capable of shortening the recalcification time of normal pooled plasma as well as both Factor VII and VIII deficient plasma but not that of plasma deficient in Factor X (Table III). The recalcification times of BAL in normal pooled and each deficient plasma were decreased after lung injury. The dependence on Factor $\mathbf{X}$ in each coagulation profile suggested the presence in baboon BAL of an activator of Factor $\mathbf{X}$. Support for a Factor $\mathbf{X}$ activator in baboon BAL was shown by activation of Factor $\mathrm{X}$ to Factor $\mathrm{Xa}$ in amidolytic assays and cleavage of purified human Factor X to form the $55,000 M_{\mathrm{r}}$ Factor Xa product (data not shown).

BAL Factor $\mathrm{X}$ activating activity was similar to that have previously reported in BAL of patients with ARDS and marmosets with bleomycin-induced lung injury $(3,8)$ and suggested that tissue factor-Factor VII complex was the major procoagulant activity present in baboon BAL. Further, this activity was sedimentable by ultracentrifugation at $100,000 \mathrm{~g}$ for $2 \mathrm{~h}$ at $4^{\circ} \mathrm{C}$, suggesting the presence of a tissue factor moiety. The Factor $\mathrm{X}$ activating activity was completely neutralized in the presence of the antibody to Factor VII (Table IV). The antibody to tissue factor was also effective in inhibiting the Factor X activating activity. Therefore, tissue factor associated with Factor VII accounts for the major procoagulant activity present in baboon BAL.

As shown in Fig. 3, the recalcification times of baseline baboon BAL in normal pooled plasma were significantly longer than those obtained any time after lung injury $(P$ $=0.04$ ). Animals given $21 \% \mathrm{O}_{2}$ also showed shorter recalcifcation times over the $11 \mathrm{~d}$. Transformation of the recalcification times to procoagulant units demonstrated that for each time measurement after lung injury significantly greater amounts of BAL procoagulant activity were present $(P<0.01)$ relative to baseline. This was the case for each DAD animal studied. BAL procoagulant activity was variably increased in $21 \% \mathrm{O}_{2}$ control baboons and was usually of lesser magnitude. In animals ventilated with $21 \% \mathrm{O}_{2}$, a focal bronchopneumonia was often observed and found to correlate with increased procoagulant activity present in BAL observed on day $7(P$ $=0.04$ ), but BAL procoagulant activity returned to baseline levels by day 11 .

Because the increase in procoagulant activity in BAL of baboons with DAD was the result of the assembly and expression of the extrinsic pathway of coagulation, i.e., Factor VII associated with tissue factor, we investigated the possible regulation of this complex by determining the degree of Factor $\mathbf{X}$ activation relative to the presence of the recently characterized extrinsic pathway inhibitor (EPI;21). The rate of Factor Xa formation was observed to increase $(P=0.04)$ and remain 

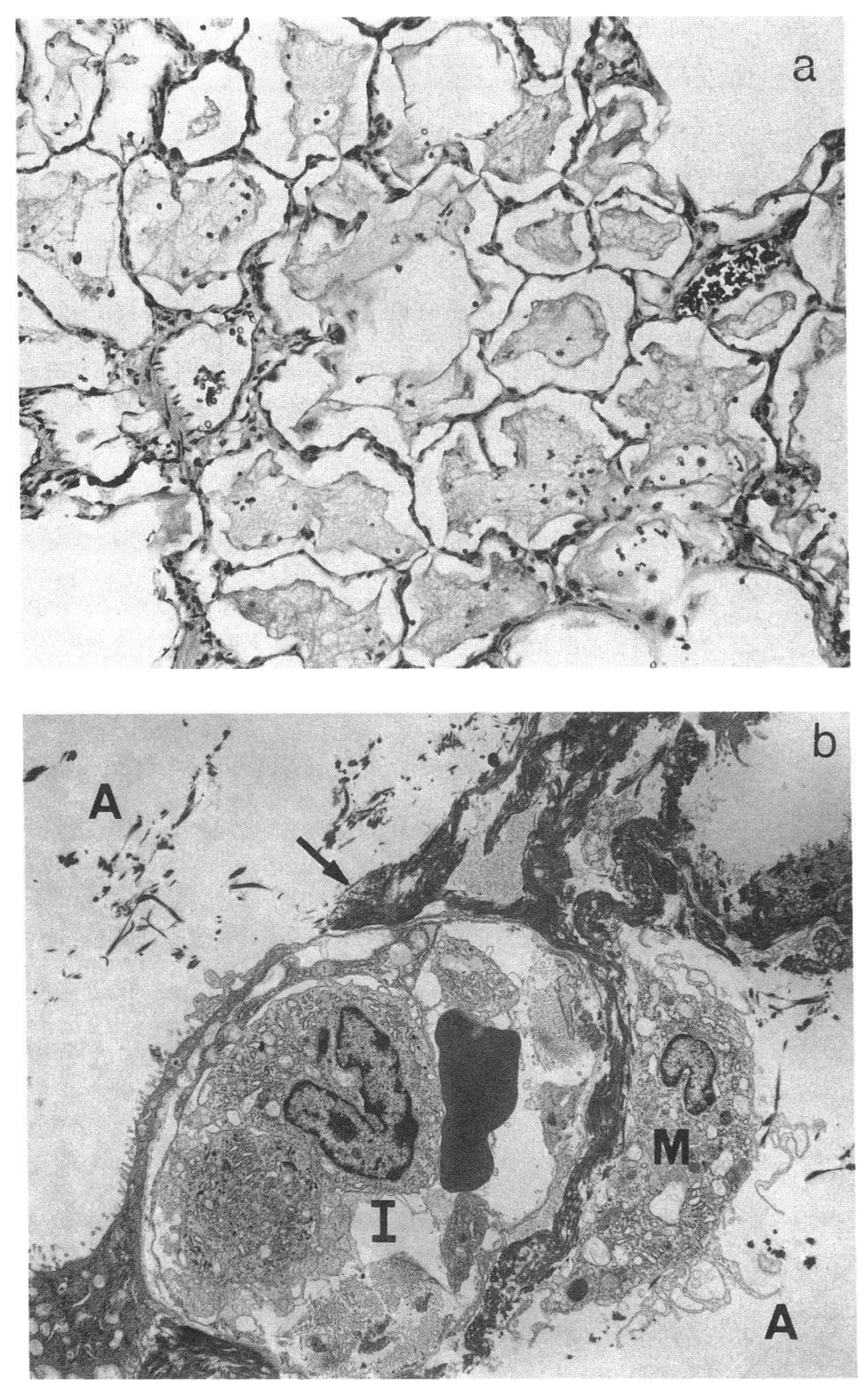

Figure 2. Histologic changes in the lungs of $100 \% \mathrm{O}_{2}$ treated baboons. (a) Protein rich edema and a few extravasated RBCs are in the alveolar spaces. Hematoxylin and eosin; $\times 140$. (b) Fibrin and an alveolar macrophage $(M)$ envelope the alveolar wall. The type I epithelial lining is focally lost (arrow). A monocyte and $\mathrm{RBC}$ are in the interstitium (I). A, Alveolar space. Lead citrate and uranyl acetate; $\times 7,800$. The arrow indicates alveolar fibrin. elevated following DAD, while a transient increase in Factor $\mathrm{Xa}$ generation was noted for $21 \% \mathrm{O}_{2}$ controls (Fig. 4). Injury with $100 \% \mathrm{O}_{2}$ indicated a clear inverse relationship between Factor $\mathrm{X}$ activation and the presence of EPI. No correlation was evident between these parameters during the period of control ventilation, although modest elevations were noted, presumably as a result of focal bronchopneumonia.

In preliminary experiments, we found that the addition of baboon plasma, or lysed or live human neutrophils to BAL shortened the recalcification times of BAL in normal pooled human plasma but failed to increase the Factor $\mathrm{X}$ activating activity of BAL. No procoagulant activity was observed in the neutrophil preparations and extremely small amounts were found in baboon plasma by recalcification, but not amidolytic assays. These data indicate that the influx of neutrophils into the lung was not responsible for the observed increase in procoagulant activity.
Characterization and quantitation of the fibrinolytic activity present in baboon $B A L$. Fibrinolytic activity was usually but not invariably detectable in unconcentrated baseline BAL (Fig. 5). In baboons ventilated with $21 \% \mathrm{O}_{2}$, fibrinolytic activity was either stable or rose somewhat after several days of mechanical ventilation, but was not significantly changed from baseline levels. In baboons with $100 \% \mathrm{O}_{2}$ injury, the $\mathrm{BAL}$ fibrinolytic activity was reduced at day 5 and undetectable by days 7 and 9 . In the $100 \%$ oxygen-treated group, one animal (No. 4081) developed only mild lung injury. In this animal fibrinolytic activity was detectable at all time points after the administration of $100 \% \mathrm{O}_{2}$. Thus, depressed fibrinolytic activity present in baboon BAL appeared to be associated with the induction of DAD. The addition of lysed or live human neutrophils increased the total fibrinolytic activity found in baseline baboon BAL. Addition of lysed or live neutrophils to BAL of baboons with evolving DAD that lacked fibrinolytic activity 
Table I. Histologic Features of $100 \%$ and $21 \%$ $\mathrm{O}_{2}$-treated Baboons

\begin{tabular}{cccccccc}
\hline & & \multicolumn{2}{c}{ DAD } & & \multicolumn{2}{c}{ Pneumonia } \\
\cline { 3 - 4 } \cline { 6 - 7 } Group & Animal No. & Focal & Diffuse & & Mild & Moderate \\
\hline $100 \% \mathrm{O}_{2}$ & $4081^{*}$ & 0 & & & $\times$ & \\
& 3825 & $\times$ & & & 0 & \\
& 3933 & $\times$ & & & $\times$ & \\
& $3917,4060,4253$ & & $\times$ & & $\times$ & \\
& 4054,4055 & & $\times$ & & $\times$ \\
$21 \% \mathrm{O}_{2}$ & $4128,4196,4242$ & 0 & & & $\times$ & \\
& 4260,4304 & & & & \\
& 4171,4238 & 0 & & & $\times$ \\
& & & & & & & \\
\hline
\end{tabular}

0, none; * No widespread pulmonary edema. Bronchopneumonia was diagnosed as follows: mild, the presence of scattered neutrophilic infiltrates localized to terminal bronchioles and surrounding alveoli; moderate, when extension of this process caused confluence of infiltrates between adjacent lobules; and severe, when the exudative process was extensively confluent both grossly and microscopically and was occasionally associated with tissue necrosis.

did not generate detectable fibrinolytic activity and the addition of baboon plasma to BAL inhibited BAL fibrinolytic activity.

Because fibrinolysis is initiated by specific plasminogen activators (PA), we characterized the components of the fibrinolytic system in BAL. The fibrinolytic activity present in baboon BAL was mainly plasminogen dependent. Plasminogen independent fibrinolytic activity was not detectable in unconcentrated BAL at any time point by the fibrin plate assay (data not shown). Further, PA activity could be neutralized by an antibody to urokinase but not by nonimmune IgG controls or an antibody specific for t-PA in the ${ }^{125} \mathrm{I}$ fibrin plate assay (Table V). When the molecular weight of the PA was investigated by fibrin gel autography, the major zone of fibrinolytic activity present in baboon BAL was found to comigrate with urokinase standards (Fig. $6 a$ ) and be neutralized by antibody to urokinase (Fig. $6 \mathrm{~b}$ ). Additional higher molecular

Table II. Morphometric Analysis of Tissue Fibrin Deposition in Baboons with DAD*

\begin{tabular}{clc}
\hline Animal No. & Histology & Density \\
\hline 4564 & DAD & 6.96 \\
4054 & DAD & 9.18 \\
4390 & DAD & 17.09 \\
971 & Normal & 0 \\
967 & Normal & 0.06 \\
968 & Normal & 0
\end{tabular}

\footnotetext{
* Controls with normal lung histology were unventilated, healthy baboons. DAD samples selected for study were randomly chosen from animals having typical histologic DAD. Volume densities, used as an index of alveolar fibrin deposition, are expressed as a percentage: Volume density $=100 \times$ fibrin, hyaline membranes/airspace.
}

Table III. Recalcification Times of Baboon BAL in Normalpooled and Factor-deficient Human Plasma*

\begin{tabular}{lrrcr}
\hline & Factor VIII & Factor VII & Factor X & NPP \\
\hline Baseline & & & & \\
$(n=4)$ & $239.2 \pm 24.6$ & $311.0 \pm 84.3$ & $>500$ & $271.6 \pm 69.0$ \\
DAD $(n=5)$ & $74.8 \pm 15.3$ & $69.7 \pm 16.1$ & $281.5 \pm 74.2$ & $65.3 \pm 13.3$
\end{tabular}

* VII, VIII, X, plasma-deficient in Factor VII, VIII, or X. NPP, normal-pooled plasma. Recalcification times are expressed in seconds. All assays were done in duplicate, using the same lots of plasma. The mean \pm standard deviation of the measured recalcification times are shown.

weight zones of fibrinolysis were identified at $M_{\mathrm{r}} 85,000$ and 110,000 and were most prominent in DAD BAL. Lytic zones were undetectable or grossly attenuated in baseline baboon $\operatorname{BAL}(n=9$ samples) when plasminogen was deleted from the indicator plates. By contrast, prominent zones of fibrinolysis at $M_{\mathrm{r}} 110,000$ but not 85,000 were found in BAL samples from baboons with DAD when plasminogen was deleted (data not shown). The $85,000 M_{\mathrm{r}}$ zone of fibrinolysis was not inhibited in the presence of either of our antibodies to u-PA or t-PA. These experiments indicate that urokinase-like fibrinolytic activity was present in baboon BAL and that plasminogen independent fibrinolytic activity could also be detected in BAL of baboons with evolving DAD using fibrin gel enzymography.

Because the BAL from baboons with DAD demonstrated lytic zones at higher molecular weight and because these BAL samples had no detectable fibrinolytic activity when studied by the fibrin plate assay, we reasoned that specific inhibitor(s) of PA or plasmin were likely to be present. Determination of BAL PA inhibitors (PAI) was monitored by reverse fibrin autography. Baseline BAL harvested before lung injury contained no detectable PAI activity, whereas these samples contained detectable u-PA activity by the fibrin plate assay and fibrin gel autography. However, after induction of lung injury leading to DAD, lysis-resistant zones were detected at 45,000 $M_{\mathrm{r}}$ in some (three of six) DAD BAL samples, indicating the presence of PAI. In separate experiments, we found that this zone of PAI migrated near that of Hep G2 cells, which are known to produce PAI-1 (35) and this zone could be inhibited by an antibody to PAI-1 (Fig. 7).

The absence of detectable fibrinolytic activity in BAL of baboons with DAD in the fibrin plate assay was not associated with local insufficiency of plasminogen substrate in these fluids. Increased levels of plasminogen were detectable in BAL of baboons with DAD or pneumonitis compared to baseline BAL $(P=0.04)$ (Fig. 8). Injury with $100 \% \mathrm{O}_{2}$ led to a progressive increase in plasminogen to very high levels over the course of $9 \mathrm{~d}$ (Fig. 8). Ventilated $21 \% \mathrm{O}_{2}$ controls showed a modest increase with time, but the levels were well below those measured in baboons with DAD.

We next investigated whether the plasminogen had been cleaved within the BAL. Plasminogen was isolated from BAL using lysine-agarose absorption and the plasminogen-related proteins separated by SDS-PAGE, transferred to nitrocellulose, and localized by immunoblotting (Fig. 9). The major plasminogen species in control or DAD BAL was the Glu-lplasminogen with an $M_{\mathrm{r}} 90,000$. Activation of the native pro- 
Table IV. Neutralization of Procoagulant Activity of Baboon BAL by Antibodies to Factor VII and Tissue Factor

\begin{tabular}{cccccccrr}
\hline Baboon BAL No. & + Buffer & $+\operatorname{lgG}$ & + VII IgG & \%INH & +Buffer & +IgG & + TFlgG & $\%$ \%INH \\
\hline 3933 & 0.163 & 0.127 & 0 & 100.0 & 0.109 & 0.091 & 0.036 & 60.4 \\
4055 & 0.309 & 0.291 & 0 & 100.0 & 0.055 & 0.073 & 0 & 100.0 \\
4353 & 0.055 & 0.055 & 0 & $\underline{100.0}$ & 0.055 & 0.055 & 0 & $\frac{100.0}{86.8}$
\end{tabular}

Baboon BAL was incubated with buffer $(0.15 \mathrm{M} \mathrm{NaCl}, 0.02 \mathrm{M}$ Tris $\mathrm{HCl}, \mathrm{pH} 7.4)$, the IgG fraction of rabbit nonimmune immunoglobulin (IgG) or the IgG fraction of antibodies to tissue factor (TFIgG) or Factor VII (VII IgG) as described in Methods. Aliquots of the reaction mixture were studied in the Factor Xa amidolytic assay, and the data are expressed in pmol/min per ml of Factor Xa activity based upon Factor Xa standards. \%INH, \% inhibition of nonimmune IgG. The concentration of TFIgG and its nonimmune control was $100 \mu \mathrm{g} / \mathrm{ml}$; that of VII IgG and its nonimmune control was $50 \mu \mathrm{g} / \mathrm{ml}$. \%INH, 1 - (activity in the presence of specific antibody divided by the activity in the presence of nonimmune IgG) multiplied by 100 . $\bar{x}$, mean value. Tissue factor antibody neutralization experiments of all samples and VII antibody neutralizations of sample $\mathbf{4 2 5 3}$ were done using a different batch of Factor X in separate experiments. The BAL samples selected for these analyses were randomly chosen from a large group of samples harvested mainly during evolving DAD and were found to have readily detectable Factor $\mathrm{X}$ activating activity in initial screening assays done to establish trends in serial BAL.

tein to Lys-77-plasminogen $\left(M_{\mathrm{r}} 81,000\right)$ and the A chain of plasmin (Lys-77-Arg 560; 56,000 $M_{\mathrm{r}}$ ) were noted in DAD samples.

Because the depressed fibrinolytic activity present in DAD BAL was associated with elevated BAL total protein, we hy-

\section{BABOON BAL PROCOAGULANT ACTIVITY}
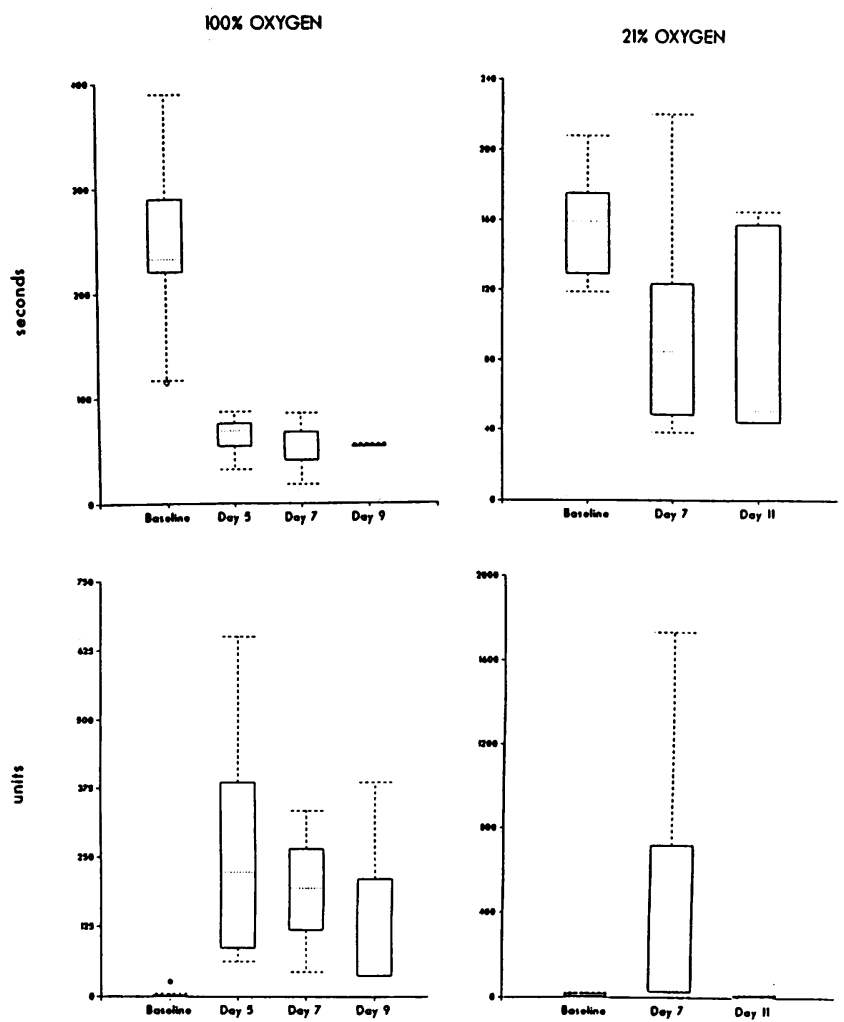

Figure 3. Procoagulant activity in serial BAL samples of baboons treated with $100 \%$ oxygen and $21 \%$ oxygen. Data are presented as recalcification times in seconds (top row) and in procoagulant units relative to a thromboplastin standard curve (bottom row) in the box plot format described in Fig. 1. Confidence limits are described in the text.

\section{BABOON BAL FACTOR X ACTIVATING ACTIVITY}

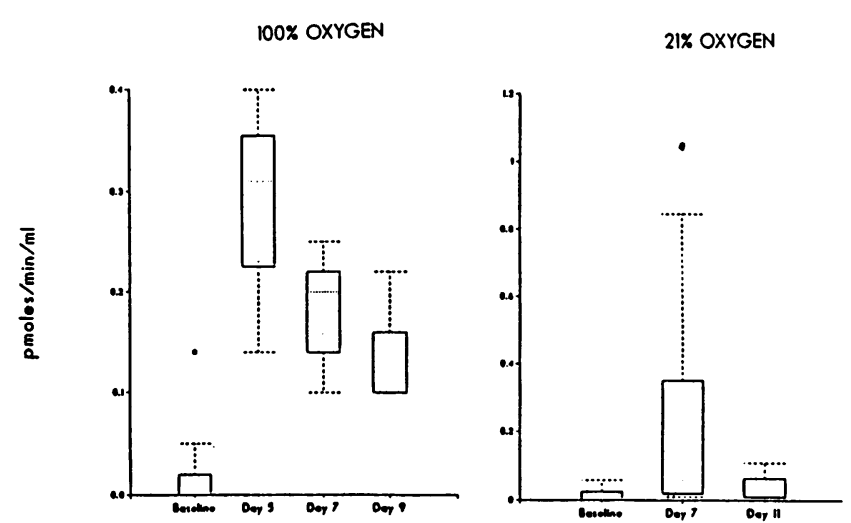

BABOON BAL EXTRINSIC PATHWAY INHIBITOR

100\% OXYGEN

$21 \%$ OXYGEN
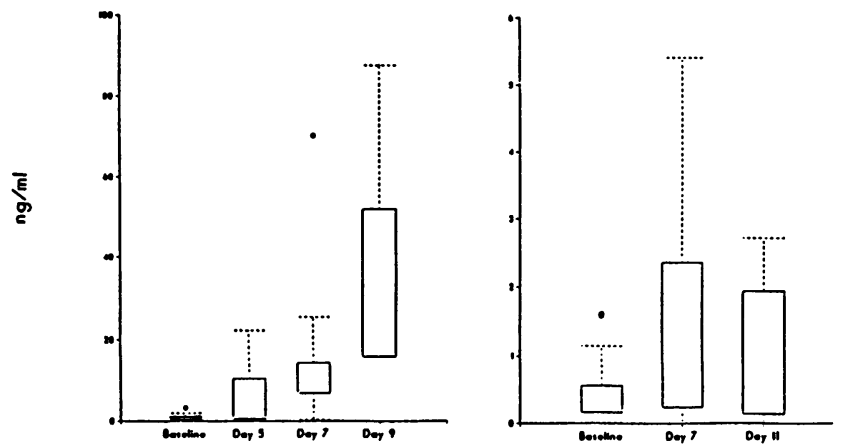

Figure 4. Factor $\mathrm{X}$ activating activity and presence of the extrinsic pathway inhibitor in serial BAL samples of baboons treated with $100 \%$ oxygen or $21 \%$ oxygen. Data are presented as Factor Xa amidolytic activity (pmol/min per $\mathrm{ml}$ ) in the top row and concentration of the extrinsic pathway inhibitor $(\mathrm{ng} / \mathrm{ml})$ relative to a normal human plasma standard (bottom row). The box plot format is described in Fig. 1. Confidence limits are described in the text. 


\section{BABOON BAL FIBRINOLYTIC ACTIVITY}
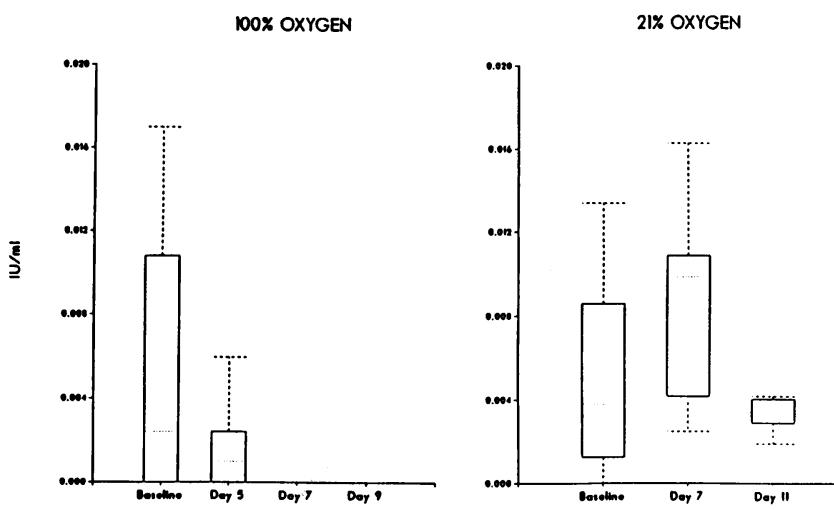

Figure 5. Fibrinolytic activity in serial BAL samples of baboons treated with $100 \%$ oxygen or $21 \%$ oxygen. Data are presented in $\mathrm{IU} / \mathrm{ml}$ relative to urokinase standards. Median values were 0 and the data range approached 0 on days 7 and 9 of $100 \%$ oxygen treatment. The box plot format is described in Fig. 1. Confidence limits are described in the text.

pothesized that baseline fibrinolytic activity was inhibited by inhibitor(s) derived from plasma that had leaked into the alveolar space. The presence of inhibitors of fibrinolysis was initially suggested on the original ${ }^{125}$ I-fibrin plates. To determine whether plasmin inhibition was responsible for the depressed BAL fibrinolytic activity after lung injury, we incubated these BAL samples with purified plasmin at a concentration predetermined to equal or to exceed the highest levels generated by the PA found in control baboon BAL. As shown in Table VI, fibrinolytic activity of the plasmin standards at 2.5 or $5 \mu \mathrm{g} / \mathrm{ml}$ was completely inhibited by the addition of BAL lacking fibrinolytic activity from baboons with DAD, indicating the presence of an active inhibitor of plasmin. Plasmin inhibitory activity was also found to increase, by amido-

Table V. Neutralization of Fibrinolytic Activity in Baboon BAL

\begin{tabular}{ccccccc}
\hline $\begin{array}{c}\text { Baboon } \\
\text { BAL No. }\end{array}$ & +NSS & +IgG & +uPAIgG & $\%$ INH & +PAIgG & $\%$ INH \\
\hline 4055 & 0.0941 & 0.0928 & 0 & 100 & 0.0955 & 0 \\
4771 & 0.0083 & 0.0082 & 0 & 100 & 0.0076 & 7 \\
4189 & 0.0958 & 0.1000 & 0 & $\underline{100}$ & 0.1000 & $\underline{0}$ \\
\multicolumn{2}{c}{ \% $\%$ INH } & & & 100 & & 2.3
\end{tabular}

BAL samples were added 1:1 with normal saline solution (NSS), the IgG fraction of goat nonimmune IgG, or the IgG fraction of antibodies to urokinase (uPAIgG) or tissue plasminogen activator (tPAIgG) as described in Methods and the average of duplicate assays of fibrinolytic activities was determined in the ${ }^{125}$ I fibrin plate assay. The final concentration of all antibodies used was $160 \mu \mathrm{g} / \mathrm{ml}$. The fibrinolytic activities shown are in IU/ml based upon urokinase standards. \%INH, inhibition compared to IgG control. $\overline{\mathbf{x}}$, mean value. The BAL samples selected for these analyses were chosen from a large group of those harvested mainly before lung injury, which were found to contain readily detectable fibrinolytic activity.

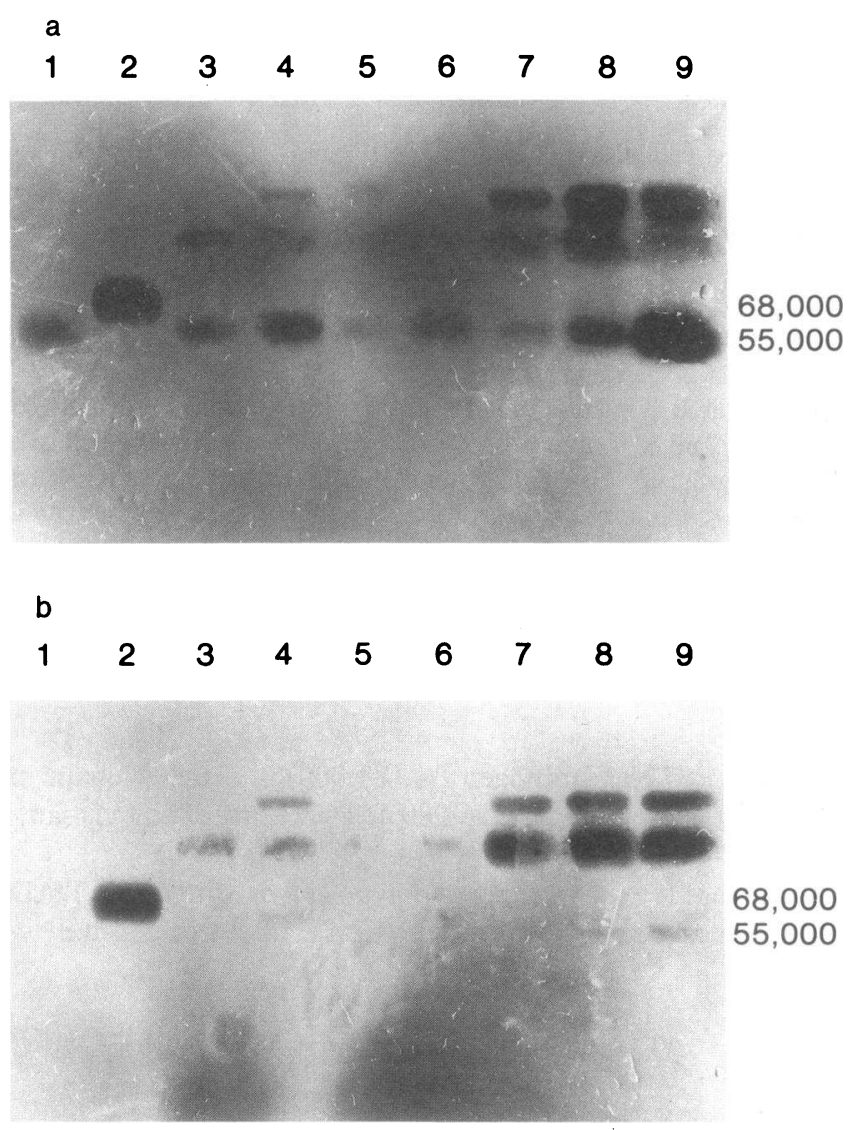

Figure 6. Fibrin plate enzymography of baboon plasminogen activator activity in BAL. Samples $(30 \mu \mathrm{l})$ were electrophoresed on SDS- $10 \%$ polyacrylamide gels under nonreduced conditions and fibrinolytic activity localized using a plasminogen and fibrin containing agarose gel. $(a)$ The fibrin enzymography plate was impregnated with $100 \mu \mathrm{g} / \mathrm{ml}$ nonimmune goat IgG. Lane $1,0.5 \mathrm{IU} / \mathrm{ml}$ urokinase standard. Lane 2, 0.130 U/ml tPA standard. Lanes 3-6 contain neat baseline or control BAL. Lanes 7-9, BAL from baboons with evolving DAD. (b) The same samples were run in an enzymography gel impregnated with $100 \mu \mathrm{g} / \mathrm{ml}$ of the IgG fraction of goat antibody to human urokinase.

lytic assay, in serial BAL during the evolution of DAD (data not shown). Baseline BAL contained little antiplasmin activity; mean fibrinolytic activity generated by $2.5 \mu \mathrm{g} / \mathrm{ml}$ plasmin mixed with baseline baboon $\mathrm{BAL}=0.2864 \mathrm{IU} / \mathrm{ml}(n=4$ samples) vs $0.3046 \mathrm{IU} / \mathrm{ml}$ generated by the plasmin standard mixed with normal saline in the fibrin plate assay. Whereas plasmin inhibitory activity was observed upon injury, little antiplasmin activity was found in baseline BAL or that of control $21 \% \mathrm{O}_{2}$ baboons by either fibrinolytic or amidolytic assays.

In order to determine whether $\alpha_{2} \mathrm{AP}$ contributed to the depressed fibrinolytic activity in BAL of baboons with evolving DAD, we adsorbed these BAL samples with goat antibody to $\alpha_{2} \mathrm{AP}$ or control goat IgG. The adsorbed samples were then tested for their ability to neutralize a $1.25-\mu \mathrm{g}$ plasmin standard in the fibrin plate assay (Table VII). The samples $(n=5)$ chosen for these experiments contained no detectable fibrinolytic activity and were obtained from baboons with acute lung injury and evolving DAD. As shown in Table VII, inhibition of plasmin-mediated fibrinolytic activity could be partially re- 

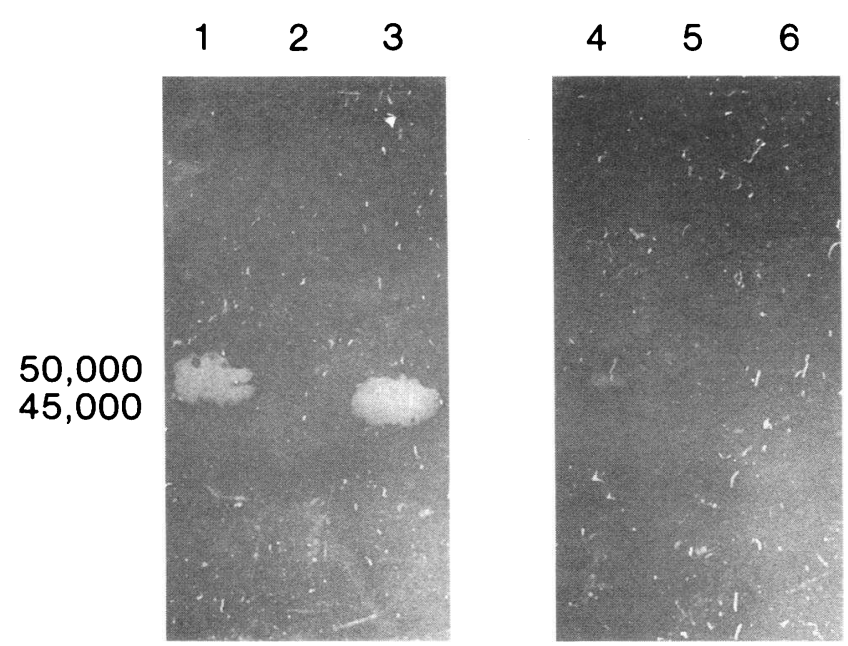

Figure 7. Presence of plasminogen activator inhibitor by reverse autography of baboon BAL. Samples $(30 \mu \mathrm{l})$ were electrophoresed on an SDS-10\% polyacrylamide gel under nonreducing conditions. PAI was localized using an agarose gel containing fibrin, plasminogen, and $0.075 \mathrm{IU} / \mathrm{ml}$ of urokinase. Lanes 1 and 4 , PAI secreted from Hep G 2 cells; lanes 2 and 5, baseline BAL; lanes 3 and 6, BAL from animal with evolving DAD. The fibrin gel overlay for the samples in lanes $1-3$ was impregnated with nonimmune rabbit $\operatorname{lgG}$ at a final concentration of $20 \mu \mathrm{g} / \mathrm{ml}$. The overlay for lanes 4-6 contained the IgG fraction of rabbit antibody to PAI-1, $20 \mu \mathrm{g} / \mathrm{ml}$.

versed in undiluted samples by adsorption with antibody to $\alpha_{2} \mathrm{AP}$. Complete or nearly complete neutralization of BALmediate inhibition of plasmin activity could be achieved with dilution of BAL in two samples. This effect corresponded to the measured concentration of $\alpha_{2} \mathrm{AP}$ antigen in BAL samples and was about one-fourth that determined in the other samples. Baseline BAL contained little or no detectable antiplasmin activity and the $\alpha_{2} \mathrm{AP}$ antigen was below the detection limits of our radioimmunoassay $(30 \mathrm{ng} / \mathrm{ml})$. Thus, BAL sam-

\section{BABOON BAL PLASMINOGEN}
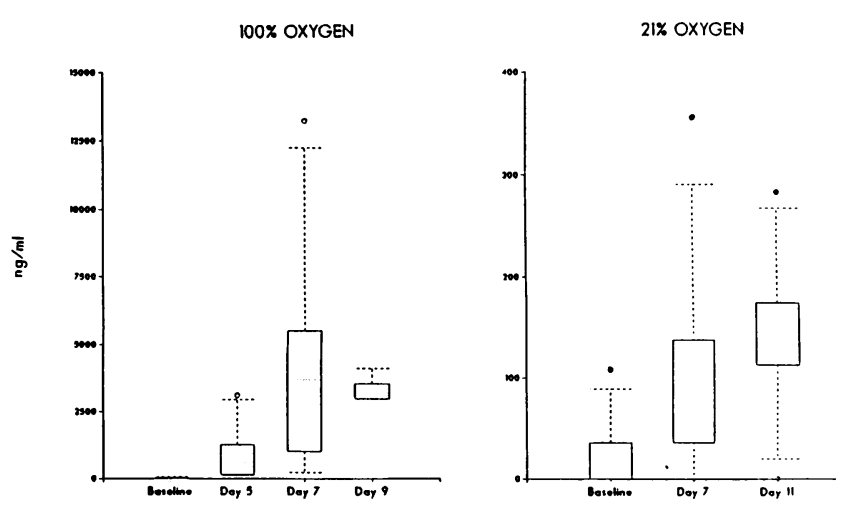

Figure 8. Plasminogen in serial BAL samples of baboons treated with $100 \%$ oxygen or $21 \%$ oxygen. The concentration of plasminogen $(\mu \mathrm{g} /$ $\mathrm{ml}$ ) was determined by radioimmunoassay. The data are presented as box plots which are described in Fig. 1. Confidence limits are described in the text.

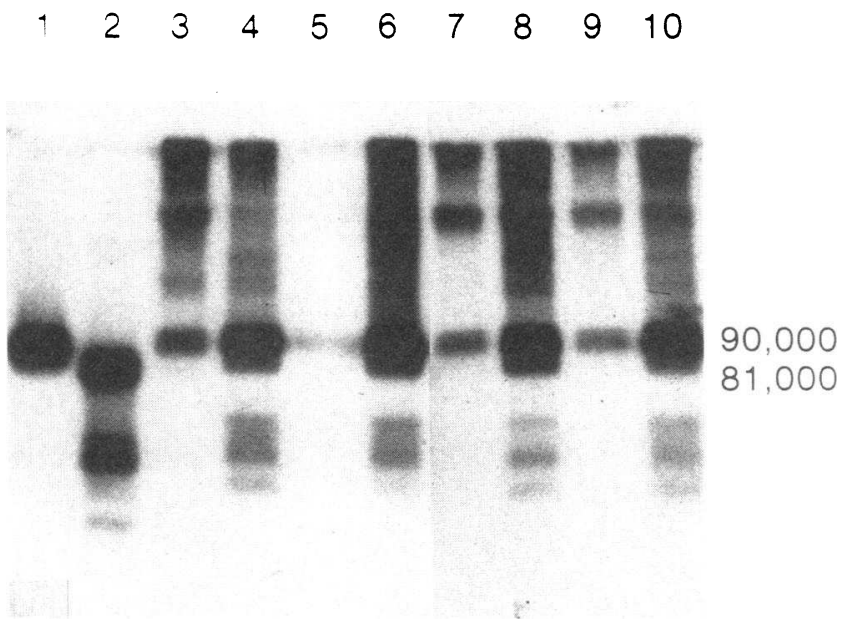

Figure 9. Immunoblot for plasminogen present in baboon BAL. Samples were absorbed with lysine-agarose beads, and the bound material separated on SDS-7\% polyacrylamide gels under reducing conditions. After transfer to nitrocellulose, the plasminogen derivatives were localized using rabbit antiplasminogen, ${ }^{125} \mathrm{I}$-goat anti-rabbit IgG and autoradiography. Lane 1, $100 \mathrm{ng}$ of Glu-plasminogen standard; lane 2, $100 \mathrm{ng}$ of a mixture of Lys-plasminogen and plasmin; lanes $3,5,7$, and 9, plasminogen species present in neat baseline BAL before induction of DAD; and lanes $4,6,8$, and 10 , plasminogen derivatives absorbed from neat BAL of the same baboons with evolving DAD.

ples obtained during development of DAD, which lacked fibrinolytic activity, contained significant amounts of antiplasmin activity.

To examine the specificity of the abnormalities of fibrin turnover we detected in BAL of baboons with DAD, we measured the procoagulant and fibrinolytic activities present in human pleural fluids which served as non-BAL controls. All pleural fluids from patients with CHF were transudative, whereas those from patients with pneumonia, empyema or carcinoma of the lung fulfilled criteria for exudates (36). Proportionately larger numbers of neutrophils were contained in

Table VI. Antiplasmin Activity of Baboon BAL

\begin{tabular}{ccccc}
\hline Plasmin concentration & \multicolumn{2}{c}{ Sample } & IU/ml & \% Inhibition \\
\hline \multirow{2}{*}{$5.0 \mu \mathrm{g} / \mathrm{ml}$} & NSS & 1.829 & - \\
& 4054 & $7-22$ & 0 & 100 \\
& 4055 & $7-23$ & 0 & 100 \\
& 4253 & $4-16$ & 0 & 100 \\
$2.5 \mu \mathrm{g} / \mathrm{ml}$ & 4153 & $4-18$ & .007 & 99 \\
& NSS & .740 & - \\
& 4054 & $7-22$ & 0 & 100 \\
& 4055 & $7-23$ & 0 & 100 \\
& 4253 & $4-16$ & 0 & 100 \\
& 4153 & $4-18$ & .007 & 99
\end{tabular}

$\%$ Inhibition $=$ Units NSS - Units BAL/Units NSS $\times 100$. All samples were run in duplicate in the fibrin plate assay described in Methods. NSS, normal saline. BAL samples used in these experiments were all from baboons with DAD. Samples used in these experiments were randomly selected from the pool of BAL harvested after lung injury that were found to contain depressed fibrinolytic activity. 
Table VII. Absorption of Antiplasmin Activity in Baboon BAL by Antibody to $\alpha_{2}$ Antiplasmin

\begin{tabular}{|c|c|c|c|}
\hline \multirow[b]{2}{*}{ Sample } & \multicolumn{2}{|c|}{ Residual fibrinolytic activity } & \multirow[b]{2}{*}{$\alpha_{2} \mathrm{AP}$} \\
\hline & +Control IgG & $+\alpha_{2} \mathrm{AP}$ IgG & \\
\hline & \multicolumn{2}{|c|}{$I U / m l$} & $n g / m l$ \\
\hline 4054 Neat & 0 & 0 & 670 \\
\hline$(7-22) 1: 2$ & 0 & 0 & \\
\hline $1: 4$ & 0 & 0 & \\
\hline $1: 8$ & 0 & 0 & \\
\hline 4253 Neat & 0 & 0 & 112 \\
\hline$(4-16) 1: 2$ & 0 & 0.0497 & \\
\hline $1: 4$ & 0.0563 & 0.0978 & \\
\hline $1: 8$ & 0.1405 & 0.1363 & \\
\hline 4253 Neat & 0 & 0 & 140 \\
\hline$(4-18) 1: 2$ & 0.0080 & 0.0152 & \\
\hline $1: 4$ & 0.0252 & 0.0706 & \\
\hline $1: 8$ & 0.1043 & 0.1461 & \\
\hline $\begin{array}{l}4055 \text { Neat } \\
(7-23)\end{array}$ & 0 & 0 & 590 \\
\hline $\begin{array}{l}4060 \text { Neat } \\
(8-5)\end{array}$ & 0.0265 & 0.0496 & 716 \\
\hline
\end{tabular}

Absorption experiments were performed as described in Methods. Control IgG, goat nonimmune IgG. $\alpha_{2}$ AP IgG, goat antihuman $\alpha_{2}$ AP IgG. Fibrinolytic activities of serial dilutions of BAL samples in the presence of the plasmin standard $(1.25 \mu \mathrm{g} / \mathrm{ml})$ were determined by ${ }^{125} \mathrm{I}$-fibrin plate assay. All BAL samples used in these experiments were from baboons with $100 \% \mathrm{O}_{2}$ exposure. Concentrations of $\alpha_{2} \mathrm{AP}$ were determined by radioimmunoassay.

exudative fluids based on total white cell and differential counts (Table VIII). Exudative pleural effusions rarely (4 of 23 exudates) contained detectable plasminogen-dependent fibrinolytic activity in the ${ }^{125} \mathrm{I}$-fibrin plate assay, whereas this fibri- nolytic activity was detectable in five of the six pleural fluid samples from patients with CHF. Shorter recalcification times, indicating increased procoagulant activity, were detectable in pleural fluids of patients with pneumonia or lung cancer compared to patients with congestive heart failure which did not differ from the recalcification times in normal pooled plasma of pleural fluids from patients with empyema. These data indicate that similar trends of both procoagulant and fibrinolytic activities occur in exudative pleural fluids and DAD BAL. Increased procoagulant activity in the setting of high-grade pleural inflammation (empyema) does not invariably occur (Table VIII), whereas it is consistently observed in BAL of all baboons during evolving DAD (Fig. 3).

\section{Discussion}

Tissue fibrin deposition represents the net effect of procoagulant mechanisms which favor fibrin formation and fibrinolysis which favors its dissolution. The balance between these processes may therefore be inferred to control fibrin deposition in the alveolar space, such as occurs in the setting of acute lung injury. Extravascular fibrin deposition, chiefly within the alveoli characterizes the exudative phase of DAD in patients with the adult respiratory distress syndrome (ARDS) (1), and may occur in association with the high grade alveolitis associated with the interstitial lung diseases (2). We chose to study the baboon model, because extensive alveolar fibrin formation uniformly accompanies the lesion of DAD in baboons with induced ARDS (5), because of phylogenetic proximity of the model to humans and because of availability of immunologic reagents which cross-react with baboon proteins. Animals were studied under conditions approximating those currently used in the care of patients with ARDS including invasive instrumentation and mechanical ventilation. We studied a model of DAD, induced by protracted exposure to hyperoxia, which is germane to clinical circumstances associated with ARDS in humans (37). Superinfection, as observed in this

Table VIII. Procoagulant and Fibrinolytic Activities in Neutrophil-containing Pleural Fluids

\begin{tabular}{|c|c|c|c|c|c|c|}
\hline Group & $\begin{array}{c}\text { Total } \\
\text { white cells }\end{array}$ & PMN & LDH & $\begin{array}{c}\text { Total } \\
\text { protein }\end{array}$ & $\begin{array}{l}\text { Recalcification } \\
\text { time in NPP }\end{array}$ & $\begin{array}{c}\text { Fibrinolytic } \\
\text { activity }\end{array}$ \\
\hline & per $\mathrm{mm}^{3}$ & $\%$ & $I U / m l$ & $m g / m l$ & $s$ & $I U / \mathrm{ml}$ \\
\hline Cancer $(n=16)$ & 1,675 & 22.0 & 225 & 4.15 & $\begin{array}{c}110.0 \\
(48.5-245.0) \\
(P=0.005)^{*}\end{array}$ & 0 \\
\hline Empyema $(n=3)$ & 8,800 & 100.0 & 2,920 & 4.00 & $\begin{array}{c}178.2 \\
(63.5,178.2,431.4) \\
(P=0.439)^{*}\end{array}$ & 0 \\
\hline Pneumonia $(n=4)$ & 1,300 & 14.0 & 376 & 4.40 & $\begin{array}{c}118.2 \\
(81.1-206.2) \\
(P=0.055)^{*}\end{array}$ & 0 \\
\hline CHF $(n=6)$ & 288 & 11.5 & 65 & 1.85 & $\begin{array}{c}205.3 \\
(179.0-285.5)\end{array}$ & $\begin{array}{l}0.0495 \\
(0-0.4)\end{array}$ \\
\hline
\end{tabular}

Median values are shown with the range of minimum and maximum values for procoagulant activities and fibrinolytic activity of the $\mathrm{CHF}$ group. Procoagulant activity, recalcification time of pleural fluid in NPP. Plasminogen-dependent fibrinolytic activity was measured in the ${ }^{125}$ I-fibrin plate assay. CHF, congestive heart failure; cancer, lung cancer, pneumonia, parapneumonic effusion. PMN, polymorphonuclear granulocytes; LDH, lactic dehydrogenase. Confidence limits of procoagulant activities vs. CHF are shown. 
study, commonly accompanies the underlying derangements associated with ARDS in humans. Further, because trended BAL data are difficult to obtain in patients with ARDS, this model provided a unique opportunity to examine evolving abnormalities of fibrin turnover in primates with comparable lung injury.

Lung injury induced by $100 \% \mathrm{O}_{2}$ in baboons was associated with an increase in BAL procoagulant activity. Recalcification times in deficient plasmas, ultracentrifugation, and antibody neutralization studies indicated that the procoagulant activity was attributable to the expression of the extrinsic activation complex; that is, tissue factor associated with Factor VII. Of interest was the apparent inverse relationship between the level of EPI and Factor Xa generation after oxygen injury. With the $100 \%$ oxygen-induced injury, there was a gradual increase in EPI with a concomitant decrease in Factor Xa production. Because the lung is relatively rich in the components of the extrinsic pathway; tissue factor and Factor VII (38), the potential for the EPI to control initiation of coagulation may be diminished, which results in a net expression of procoagulant activity. The increase in lower respiratory tract procoagulant activity in baboons with DAD is similar to that which we and others have previously described in the BAL of human subjects and marmosets $(3,8,38,39)$. The observation of modestly augmented procoagulant activity in BAL of some of the baboons mechanically ventilated with $21 \%$ oxygen is not surprising, in as much as these animals often developed superinfection with histologic evidence of purulent pneumonitis.

Fibrinolytic activity present in baboon BAL was found to be immunologically cross-reactive with antibodies to human urokinase. It has previously been reported that urokinase-like fibrinolytic activity is readily detectable in BAL of normal human subjects (39). We found that a similar, if not identical, PA was usually present in baboon BAL under normal circumstances. In the absence of clinically apparent lung disease or superimposed pneumonitis, BAL contained relatively large amounts of fibrinolytic activity and at that same time had relatively small amounts of procoagulant activity. The net effect of these combined processes would be to favor fibrin dissolution. This baseline procoagulant-fibrinolytic balance in alveolar lining fluids probably explains the absence of fibrin within the alveoli under normal circumstances. Previously, it has been found that fibrinogen is not a resident protein of the alveolar lining fluids and that fibrin is not normally found at extravascular or intravascular sites within the normal lung (1, 40). Our morphometric and histologic findings support these observations as well as the notion that the local balance between procoagulant activity and fibrinolysis in alveolar fluids is a crucial determinant of alveolar fibrin deposition within the lung.

Following the induction of DAD, abnormalities of the local procoagulant-fibrinolytic balance were apparent. The pattern observed in BAL was that of augmented procoagulant activity in association with depressed fibrinolytic activity. These disturbances would be expected to additively favor tissue fibrin deposition. We found that this local disruption of the procoagulant-fibrinolytic balance was temporally associated with alveolar fibrin formation both histologically and morphometrically in baboons with DAD. These observations are unlikely to be solely attributable to the contamination of DAD BAL by plasma-derived or leukocyte proteases as: (a) the addition of baboon plasma, and to a lesser extent, lysed or live neutrophils could shorten the recalcification times of BAL in plasma but did not generate increased Factor $\mathrm{X}$-activating activity and $(b)$ the addition of lysed or live neutrophils, in quantities comparable to those originally harvested, failed to generate increased fibrinolytic activity in DAD BAL. Similar trends of procoagulant and fibrinolytic activities occurred in association with exudative pleural disease, indicating that locally disordered fibrin turnover is not specific to the alveolar space in DAD but may also accompany exudative processes in the pleural compartment. The lack of consistently increased procoagulant activity in empyema fluids is consistent with previous reports (41) and indicates that high-grade inflammation in the pleural space is not invariably associated with increased local procoagulant activity, such as consistently occurs in BAL during evolving DAD.

In addition to PA, low levels of substrate plasminogen are present in the native form in the normal lung. It is probable that PAI keeps the system regulated under normal homeostasis. Upon injury, plasminogen is increased, but we paradoxically measured a decrease in fibrinolysis. Depressed fibrinolytic activity present in BAL obtained from animals with evolving DAD was contingent upon antiplasmin activity in these BAL samples, which was potent enough to inhibit expression of levels of fibrinolytic activity generated by levels of PA present in control BAL. Baseline baboon BAL samples or those of control baboons ventilated with $21 \% \mathrm{O}_{2}$ contained little or no antiplasmin activity, while BAL samples from baboons with evolving DAD contained large amounts of antiplasmin activity. These observations suggest that inhibition of plasmin by constituent(s) of BAL from baboons with evolving DAD is in large part responsible for the depressed fibrinolytic activity found in these samples. Inhibition of plasmin was, in part, due to $\alpha_{2}$ antiplasmin, which likely entered the alveolar space as a result of microvascular injury, but could be locally elaborated as well. This observation does not preclude the possibility that other inhibitors, notably PAI-1 or PAI-2, could also depress fibrinolytic activity in the alveolar lining fluids in the setting of lung injury. Indeed, we found PAI activity, due to PAI-1, in BAL of baboons after, but not before induction of DAD, suggesting that a dual mechanism of inhibition (one for PA and one for plasmin) may account for the local depression of fibrinolytic activity in the injured primate lung.

The virtually universal occurrence of alveolar fibrin in the inflamed alveolar compartment suggests the possibility that tissue fibrin deposition and the procoagulant-fibrinolytic balance in alveolar fluids may be of importance in the pathogenesis of acute lung injury and repair. In a process analogous to that which occurs during normal wound healing (42), it is likely that intraalveolar fibrin provides an abnormal matrix for the subsequent deposition of fibrous tissue. It has previously been shown that fibrin deposits occur at sites of pulmonary scar formation $(43,44)$. In addition, fibrin and fibronectin form a suitable matrix for attraction of fibroblasts with resultant secretion of collagen in vitro (14). The relationship between the observed local abnormalities of pathways of fibrin turnover and fibrin deposition in the pathogenesis of DAD and accelerated pulmonary fibrosis remains to be established and is contingent upon the results of specific interventions that are designed to interrupt these pathways and arrest alveolar fibrin deposition in DAD. Our data provide the rationale for such interventions and suggest the feasibility of strategies which target abnormalities of either coagulation or fibrinolytic 
pathways in DAD. We conclude that locally disordered fibrin turnover, based upon multiple, concurrent, prothrombotic abnormalities of pathways of both coagulation and fibrinolysis, accompanies increased alveolar fibrin deposition in the lungs of baboons with DAD.

\section{Acknowledgments}

The authors wish to thank Ms. Frankie Barnes and Ms. Mittie Marshall for their help in preparing the manuscript and Dr. Jerry McLarty for his help with statistical analyses.

This work is supported by National Institutes of Health Clinical Investigator Award HL-01603, HL-37770, HL-23578, and HL-36536, a grant from the American Heart Association, Texas Affiliate and the Gina Sabatasse Research Grant Award. This work was done during the tenure of Dr. Fair's Established Investigator Award from the American Heart Association with funds contributed by the Texas affiliate.

\section{References}

1. Bachofen, M., and E. F. Weibel. 1982. Structural alterations of lung parenchyma in the adult respiratory distress syndrome. Clin. Chest Med. 3:35-56.

2. Jackson, L. K. 1982. Idiopathic pulmonary fibrosis. Clin. Chest Med. 3:579-592.

3. Idell, S., K. K. Gonzalez, C. K. MacArthur, C. Gillies, P. N. Walsh, J. McLarty, and R. S. Thrall. 1987. Bronchoalveolar lavage procoagulant activity in bleomycin-induced lung injury in marmosets: characterization and relationship to fibrin deposition and fibrosis. $\mathrm{Am}$. Rev. Respir. Dis. 136:124-133.

4. Sitrin, R. G., P. G. Brubaker, and J. Fantone. 1987. Tissue fibrin deposition during acute lung injury in rabbits and its relationship to local expression of procoagulants and fibrinolytic activities. Am. Rev. Respir. Dis. 135:930-936.

5. Johanson, W. G., Jr., J. R. Holcomb, and J. J. Coalson. 1982. Experimental diffuse alveolar damage in baboons. Am. Rev. Respir. Dis. 126:142-151.

6. Campbell, G. D., J. J. Coalson, and W. G. Johanson, Jr. 1984. The effect of bacterial superinfection on lung function after diffuse alveolar damage. Am. Rev. Respir. Dis. 129:974-978.

7. Holter, J. F., J. E. Weiland, E. R. Pacht, and J. E. Gadek. 1986. Protein permeability in the adult respiratory distress syndrome. $J$. Clin. Invest. 78:1513-1522.

8. Idell, S., K. Gonzalez, H. Bradford, C. MacArthur, A. M. Fein, R. Maunder, J. G. N. Garcia, D. Griffith, J. E. Weiland, T. K. Martin, J. McLarty, D. S. Fair, P. N. Walsh, and R. W. Colman. 1987. Procoagulant activity in bronchoalveolar lavage in the adult respiratory distress syndrome: contribution of tissue factor associated with Factor VII. Am. Rev. Respir. Dis. 136:1466-1474.

9. Rowland, F. N., M. J. Donovan, P. T. Picciano, G. D. Wilner, and D. L. Kreutzer. 1984. Fibrin-mediated vascular injury: identification of fibrin peptides that mediate endothelial cell retraction. Am. J. Pathol. 117:418-428.

10. Dang, C. V., W. R. Bell, D. Kaiser, and A. Wong. 1985. Disorganization of cultures vascular endothelial cell monolayers by fibrinogen fragment, D. Science (Wash. DC). 227:1487-1490.

11. Sueishi, K., S. Nannon, and K. Tanaka. 1981. Permeability enhancing and chemotactic activities of lower molecular weight degradation products of human fibrinogen. Thromb. Haemostasis. 45:9094.

12. Ciano, P. S., R. B. Colvin, and H. F. Dvorak. 1986. Macrophage migration in fibrin get matrices. Lab. Invest. 54:62-70.

13. Senior, R. M., W. F. Skodgen, G. L. Griffen, and G. D. Wilner. 1986. Effects of fibrinogen derivatives upon the inflammatory response. J. Clin. Invest. 77:1014-1019.
14. Grinnel, F., M. Feld, and D. Minter. 1980. Fibroblast adhesion to fibrinogen and fibrin: requirement for cold-insoluble globulin (plasma fibronectrin). Cell. 19:517-525.

15. Sundsmo, J. S., and D. S. Fair. 1983. Relationships among the complement, kinin, coagulation and fibrinolytic systems. Springer Semin. Immunopathol. 6:231-258.

16. McDowell, E. M., and B. F. Trump. 1976. Histologic fixatives suitable for diagnostic light and electron microscopy. Arch. Pathol. Lab. Med. 100:405-414.

17. Stenberg, P. E., M. A. Shuman, S. P. Levine, and D. F. Bainton. 1984. Optimal techniques for the immunocytochemical demonstration of B-thromboglobulin, platelet factor 4, and fibrinogen in the alphagranules of unstimulated platelets. Histochem. J. 16:983-1001.

18. Scherle, W. 1970. A simple method for volumetry of organs in quantitative stereology. Mikroskopie. 26:57-60.

19. Matthews, J. L., and J. H. Martin. 1971. Atlas of human histology and ultrastructure. Lea and Febiger, Philadelphia, PA. 96.

20. Weibel, E. R. 1979. Stereological techniques for electron microscopic morphometry. In Stereological Methods. Practical Methods for Biology and Morphometry. Vol. 1. Academic Press, Inc., London/ New York 109-122.

21. Broze, G. J., and J. P. Miletich. 1987. Characterization of the inhibition of tissue factor in serum. Blood. 69:150-158.

22. Fair, D. S. 1983. Quantitation of Factor VII in the plasma of normal and warfarin-treated individuals by radioimmunoassay. Blood. 62:784-791.

23. Dvorak, H. F., L. Van DeWater, A. M. Bitzer, A. M. Dvorak, D. Anderson, S. Harvey, R. Bach, G. L. Davis, W. DeWolf, and A. C. A. Carvalho. 1983. Procoagulant activity associated with plasma membrane vessels shed by culture tumor cells. Cancer Res. 43:43344342.

24. Bach, R., Y. Nemerson, and W. Konigsberg. 1981. Purification and characterization of bovine tissue factor. J. Biol. Chem. 256:83248331.

25. Unkeless, J. C., S. Gordon, and E. Reich. 1974. Secretion of plasminogen activator by stimulated macrophages. J. Exp. Med. 139:834-850.

26. Idell, S., B. T. Peterson, K. K. Gonzalez, L. D. Gray, R. Bach, J. McLarty, and D. S. Fair. 1988. Local abnormalities of coagulation and fibrinolysis and alveolar fibrin deposition in sheep with oleic acid-induced lung injury. Am. Rev. Respir. Dis. 138:1282-1294.

27. Levin, E. G., D. S. Fair, and D. J. Loskutoff. 1983. Human hepatoma cell line plasminogen activator. J. Lab. Clin. Med. 102:500-508.

28. Erickson, L. A., D. A. Lawrence, and D. J. Loskutoff. 1984. Reverse fibrin autography: a method to detect and partially characterize protease inhibitors after sodium dodecyl sulfate polyacrylamide gel electrophoresis. Anal. Biochem. 137:454-463.

29. Fair, D. S., and E. F. Plow. 1983. Synthesis and secretion of the fibrinolytic components, including alpha-2-antiplasmin, by a human hepatoma cell line. J. Lab. Clin. Med. 101:372-384.

30. Fair, D. S., E. F. Plow, and T. S. Edgington. 1979. Combined functional and immunochemical analysis of normal and abnormal human Factor X. J. Clin. Invest. 64:884-894.

31. Deutsch, D. G., and E. T. Mertz. 1980. Plasminogen: purification from human plasma by affinity chromatography. Science (Wash. DC). 170:1095-1097.

32. March, S. C., I. Parikh, and P. Cuatrecasas. 1974. A simplified method for cyanogen bromide activation of agarose for affinity chromatography. Anal. Biochem. 60:149-152.

33. Laemmli, U. K. 1979. Cleavage of structural proteins during assembly of the head of bacteriophage T4. Nature (Lond.). 227:680685.

34. Tobin, H., T. Staekelin, and J. Jordan. 1979. Electrophoretic transfer of proteins from polyacrylamide gels to nitrocellulose sheets: procedure and some applications. Proc. Natl. Acad. Sci. USA. 76:4350-4354. 
35. Springers, E. D., H. M. G. Princen, T. Kooistra, and V. W. M. Van Hinsbergh. 1985. Inhibition of plasminogen activators by conditioned medium from human hepatocytes and hepatoma cell line Hep G2. J. Lab. Clin. Med. 105:751-758.

36. Light, R. W., M. I. MacGregor, and P. C. Luchsinger. 1972. Pleural effusions: the diagnostic separation of transudates and exudates. Ann. Intern. Med. 77:507-513.

37. Rinaldo, J. E., and R. M. Rogers. 1982. Adult respiratory distress syndrome. Changing concepts of lung injury and repair. $N$. Engl. J. Med. 306:900-909.

38. Chapman, H. A., M. Stahl, C. L. Allen, R. Yee, and D. S. Fair. 1988. Regulation of the procoagulant activity within the bronchoalveolar compartment of normal human lung. Am. Rev. Respir. Dis. 137:1417-1425.

39. Chapman, H. A., C. L. Allen, and O. L. Stone. 1986. Abnor- malities in pathways of alveolar fibrin turnover among patients with interstitial lung disease. Am. Rev. Respir. Dis. 133:437-443.

40. Bell, D. Y., J. A. Haseman, A. Spoek, G. McSennan, and G. E. R. Hook. 1981. Plasma proteins of the bronchoalveolar surface of the lungs of smokers and nonsmokers. Am. Rev. Respir. Dis. 124:72-79.

41. Glauser, F. L., P. T. Otis, R. I. Levine, and W. R. Smith. 1975. In vitro pleural fluid clottability and fibrinogen content. Chest. 68:205-208.

42. Dvorak, H. F. 1986. Tumors: wounds that do not heal. N. Engl. J. Med. 315:1650-1659.

43. Pratt, P. 1978. The lung, structure, function and disease. Williams and Willcius Co., Baltimore, MD. 45-47.

44. Spencer, H. 1977. Pathology of the lung. 3rd ed. W. B. Saunders Co., Philadelphia, PA. 235-240. 